\title{
ACTUAL MONOGRAPH ON THE STRATEGY FOR THE DEVELOPMENT OF LOW CARBON LAND USE IN THE CONTEXT OF CLIMATE CHANGE ${ }^{1}$
}

Review for the monograph by Anatolii Kucher «Strategic directions of the development of low carbon land use to strengthen resilience to climate change» is presented.

\section{АКТУАЛЬНА МОНОГРАФІЯ ЩОДО СТРАТЕГІї РОЗВИТКУ НИЗЬКОВУГЛЕЦЕВОГО ЗЕМЛЕКОРИСТУВАННЯ В КОНТЕКСТІ ЗМІН КЛІМАТУ}

Представлено рецензію на монографію Анатолія Кучера «Стратегічні напрями розвитку низьковуглецевого землекористування як запоруки стійкості до змін клімату».
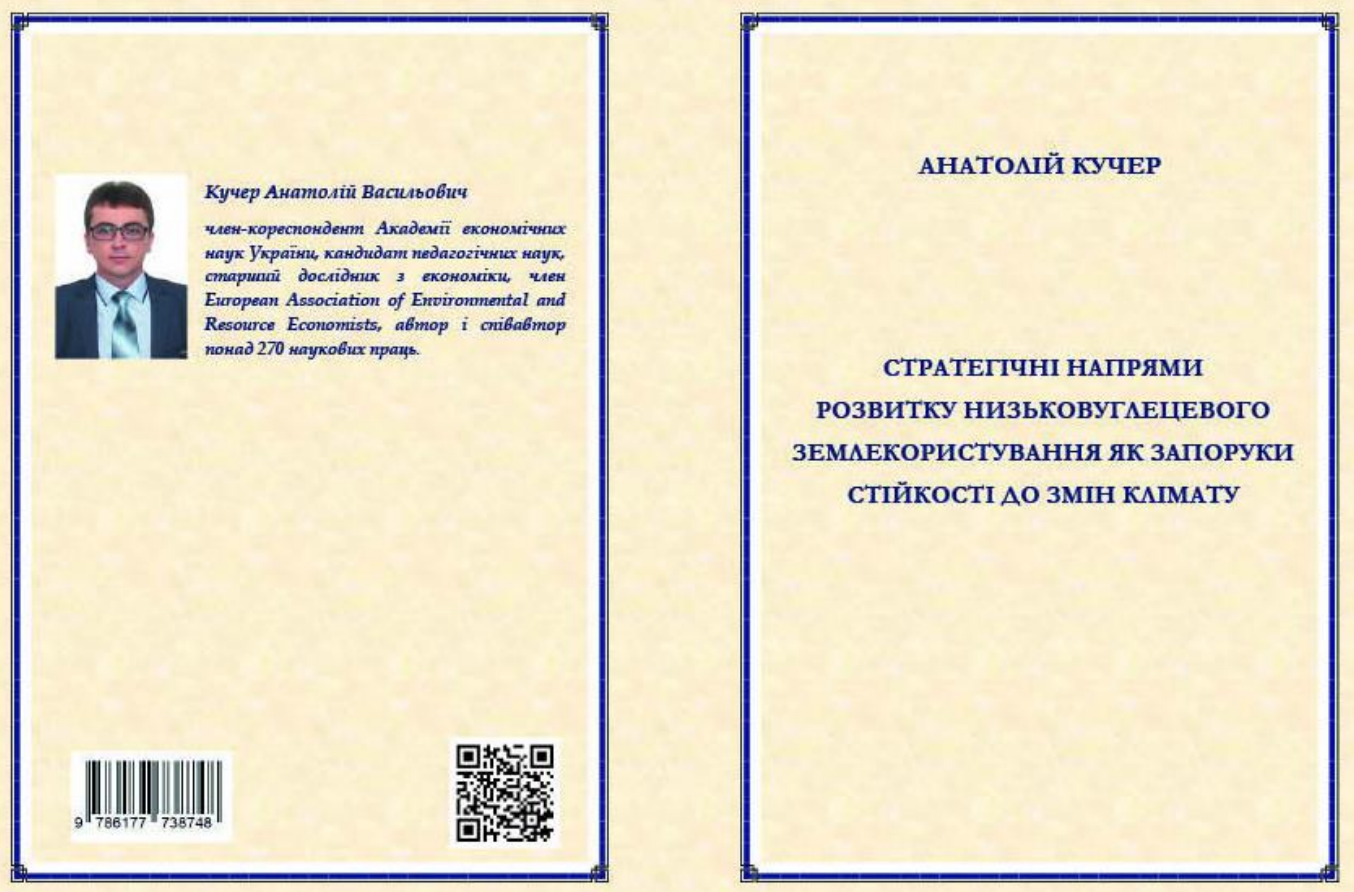

${ }^{1}$ Review for the monograph by A. V. Kucher «Strategic directions of the development of low carbon land use to strengthen resilience to climate change». Kharkiv: Publisher Brovin, 2019. 202 p. https://doi.org/10.13140/RG.2.2.22016.38400.

${ }_{2}^{2}$ Рецензія на монографію А. В. Кучера «Стратегічні напрями розвитку низьковуглецевого землекористування як запоруки стійкості до змін клімату». Харків: ФОП Бровін О. В., 2019. 202 с. https://doi.org/10.13140/RG.2.2.22016.38400. 
According to a new FAO's document «Recarbonization of global soils - A tool to support the implementation of the Koronivia Joint Work on Agriculture», «The implementation of proven Soil Organic Carbon (SOC)-centred Sustainable Soil Management (SSM) practices for maintaining carbon rich soils (peatlands, black soils, etc.) and for sequestering more carbon in soils with such potential (croplands and degraded soils), would address the challenge of compensating global greenhouse gas (GHG) emissions. Soil organic carbon sequestration has been shown to hold the largest sink potential in terrestrial ecosystems and agroecosystems. SOC-centred SSM practices could not only mitigate GHGs emissions but also provides multiple benefits such as enhancing food security and farm income, reducing poverty and malnutrition, providing essential ecosystem services (climate and hydrological regulation, biodiversity maintenance, and nutrient cycling, among others), contributing to the achievement of the Sustainable Development Goals and building resilience to extreme climatic events». As we know, the «increased SOC has been identified as one of the most cost-effective options for climate change adaptation and mitigation, as well as combating desertification, land degradation and food insecurity by the IPCC's special report on climate change and land». FAO and its Global Soil Partnership have established «RECSOIL: Recarbonization of global soils» as an initiative to move the SOC agenda into action, and to support and improve the national and regional GHG mitigation and carbon sequestration initiatives. Therefore, the above indicates the great importance, relevance and scientific value of the reviewed monograph «Strategic directions of the development of low carbon land use to strengthen resilience to climate change».

The reviewed monograph is a first attempt to close the research gap in the scientific literature and to promote research on the formation of ecological-andeconomic basis of strategic directions of the development of low carbon land use to strengthen resilience to climate change in Ukraine. This monograph presents the new holistic conception of the sustainable management of SOC in the context of climate change, which conceptually reflects the author's view on the solution of the problem raised. The framework of proposed holistic conception consists of five interrelated blocks (concepts): target, subject-object, informational, organizational-technological and effective (resultant). Each of them includes a number of conceptual, strategic and project-technological provisions, the use of which creates a methodological framework for managerial decision-making.

The monograph is structurally composed of the introduction, the main part, the general conclusions, references and annexes. The main part of the monograph consists of three chapters: 


\section{Agricultural and Resource Economics}

www.are-journal.com

Chapter 1. Environmental-and-economic basis of the development of low carbon land use, to strengthen resilience to climate change.

Chapter 2. Ecosystem bases of estimation of damage from loss of organic carbon from soil.

Chapter 3. Strategic directions for the development of low carbon land use.

The first chapter of the reviewed monograph addresses the environmental-andeconomic basis of the development of low carbon land use, to strengthen resilience to climate change, including: (i) projected climate change and economic soil fertility; (ii) adaptation of agricultural land use to climate change; and (iii) conception of sustainable management of soil organic carbon in the context of food security and climate change. The leading role of Ukraine in the formation of global food security is shown. The estimation of contribution of Ukrainian soils in global problem of carbon sequestration is carried out. Scales of losses of SOC due to irrational use of lands in agricultural enterprises are analyzed.

The second chapter includes three sections: (i) ecosystem approach to assessing damage from soil degradation under climate change; (ii) environmental-andeconomic assessment of damage from organic carbon loss from soil at different levels of management; and (iii) environmental-and-economic assessment of $\mathrm{CO}_{2}$ emissions under different levels of anthropogenic pressure. As a result of the study, the ecosystem bases of estimation of damage from loss of organic carbon from soil are substantiated and tested. It is proposed an author's scientific-and-methodical approach to quantify economic (monetary) evaluation of the environmental effect from preventing carbon dioxide emissions from the soil of agricultural lands at different levels of anthropogenic load. For the first time, a one- and two-factor linear econometric models of the dependence of the economic value of soil ecosystem services from the content of organic carbon and macronutrients in the soil in agricultural enterprises of Ukrainian regions was developed.

The third chapter is concerned with strategic directions for the development of low carbon land use. The macroeconomic assessment of potential of low carbon land use in Ukraine is described in section 3.1. In turn, section 3.2 explored analysis of environmental-and-economic benefits of strategic agrarian measures to regulate soil carbon mode; section 3.3 provided the analysis of potential sources of funding of development of low carbon agricultural land use. The results of the study of effect of the balance of organic carbon on the formation of sustainable competitiveness of agricultural enterprises are represented in section 3.4. The main strategic directions of the sustainable management of SOC in the Ukrainian agricultural sector for support/increase of its stores and maintenance of neutral degradation of lands are 


\section{Agricultural and Resource Economics \\ www.are-journal.com}

considered. The offers in plans of action for augmentation of potential of management over the sequestration of organic carbon are stated. It was identified and quantified, for the first time, the impact of the balance of organic carbon in the soil on the formation of sustainable competitiveness of agricultural enterprises. For the first time, a two-factor linear mathematical model of the dependence of the balance of humus in the soil from the yield of by-products (straw) and the volume of organic fertilizers applied in Ukrainian agricultural enterprises was developed.

So, the monograph «Strategic directions of the development of low carbon land use to strengthen resilience to climate change» meets the requirements applicable for this type of scientific works. It should be noted that the monograph contains the results of studies conducted by Grant of the President of Ukraine for competitive projects F75/192-2018 of the State Fund for Fundamental Research. This monograph provides with valuable knowledge on the ecological-and-economic basis of strategic directions of the development of low carbon land use to strengthen resilience to climate change in Ukraine. At the same time, the monograph would be more valuable if the author developed a holistic strategy for the development of low carbon land use in agriculture in Ukraine for the period up to 2030 and/or 2050. This may be one of the promising areas of research of the author.

The reviewed monograph may be recommended for policymakers, academic researchers, specialists of state administration, managers of agricultural enterprises and farmers, professors, graduates and students of higher education institutions. Thus, the research results presented in the monograph may be suitable for scientific and practical use, in particular in the development and implementation of climate and land protection policies. 